\title{
ARTICLES \\ SOME NUCLEAR-RELATED ISSUES OF MONGOLIA
}

\section{J.Enkhsaikhan}

About a year ago one of the visiting scholars was quite surprised when he learned that Mongolia has its own nuclear policy. Asheadmiited, he had no idea that Mongolia faced nuclear-related problems and that they directly affected the country's foreign and security policies. The brief exchange with this person prompted this author to try to help fill the gap by identifying the most pressing nuclear-related problems that Mongolia is currently facing and by describing the measures it is taking to tackle them.

\section{Nuclear Threat}

Mongolia, as a peace-loving country, has a strong commitment to the nonproliferation of nuclear weapons and the peaceful use of nuclear energy. It was one of the first countries that signed and ratified the 1968 Non-Proliferation Treaty (NPT), the 1963 Limited Test Ban Treaty, the 1967 Outer Space treaty, and the 1971 Seabed Treaty, all of which contribute to checking and containing the nuclear threat

In the summer of 1972 Mongolia, already party to the NPT, signed with the International Atomic Energy (IAEA) a comprehensive safeguards agreement, covering all its current and future nuclear activities and a protocol thereto.

Since then Mongolia has been actively participating in the work of the Agency's General Conference and its other bodies. For more than two decades it has been cooperating with the Agency in various fields and has jointly implemented numerous small projects. In 1995-96 the Agency and Mongolia will cooper-ate on such projects as manpower development and nuclear tech-nology support, development of nuclear analytical techniques, the introduction of nuclear techniques in agriculture, improving livestock productivity and health, and upgrading nuclear medic cine services. Mongolia plans to join other countries in making with using gamma rays to extend the freshness of meat, milk and vegetables without refrigeration, treating patients with radiation and in the early detection of genetic disorders in infants, of can-cer, heart disease and other ailments. Despite energy shortages, as of 1994 Mongolia has no plans to develop nuclear energy. 
In the international arena, on most nuclear-related issues, especially those connected with nuclear disarmament and the reduction of the danger of nuclear war, Mongolia has been strongly in favor of halting the nuclear arms race and of developing nu-clear cooperation solely for peaceful purposes.

Nevertheless, despite its consistent peace-loving policy, from the mid1960s until the mid - 1980s Mongolia, being caught in the middle of the SinoSoviet ideological and political dispute, was under the constant threat of the dispute escalating into open conflict. With Soviet troops stationed on its territory*, Mongolia had no guarantee that the Sino-Soviet conflict would not affect or engulf it nor that only conventional weapons would be used if open warfare were to erupt.

The geopolitical and security environment of Mongolia began to change as a result of the policy of perestroika and the new political thinking in the Soviet Union in the late 1980s. The main factors that influenced the external environment were the normalization of Sino-Soviet relations; gradual changes in the Soviet-Mongolian "special" relationship, and, above all, the dissolution of the Soviet Union, up to 1990 the sole guarantor of Mongolia's external security. Deideologization of Mongolia's foreign and domestic policies, the pursuit of an open economic policy abroad, the democratization of society, and the transition to a market economy have also influenced Mongolia's policy. This led to the revaluation of Mongolia's security policy as well as of its relations with both neighbors. Short of declaring that it would henceforth adhere to the principle of a balanced relationship between its neighbors, in Mongolia's relations with them due ac-count would be taken of their policies in regard to its own national interests, above all its vital national interests.

Furthermore, it was announced that a policy of non-align-ment and neutrality would be pursued in relation to disputes that might arise between the two neighbors, unless they affected Mongolia's vital national interests. Bearing in mind the limited policy choices it had in the past, Mongolia has declared that it would seek to follow a multi-based policy, i.e. that it would aim to diver-sify and expand its relations with other countries, especially with influential ones. Mindful of its previous experiences, Mongolia also declared that in pursuance of the policy of ensuring its security principally by political means, it would not allow the use of its territory against other states. This policy is in line with the RussoChinese joint statement to the effect that they would not use territories or airspace of adjacent countries against each other.

* According to some sources, about 60,000 Soviet troops were stationed in Mongolia in 1967, a number that rose to more than 75,000 by the end of the 1970s. 
In accordance with this policy, Mongolia has signed bilateral treaties of friendly relations and cooperation with Russia and China. In both cases the parties pledged not to participate in any military-political alliances directed against the other party, not to conclude with third states any treaties and agreements that would run counter to the interest of sovereignty and independence of the other party, and that they would not allow the use of their territory by third states for hostile actions against the other party. Moreover, in the treaty with the Russian Federation, the Russian side pledged to respect neither Mongolia's policy of not allowing foreign troops nor nuclear and other weapons of mass destruction to be stationed on or to transit its territory.

\section{Nuclear-weapons-free Zone (NWFZ)}

Mindful of the two decades of nuclear threat that hung over Mongolia, in September of 1992 Mongolia's President P.Ochirbat declared Mongolia a nuclearfree zone. This policy was not only aimed at ensuring its own security by political means, but by implication Mongolia was also making a contribution to regional stability and predictability. It also hoped to set a precedent for other states to ensure their security not through possessing but rather by renouncing the acquisition and stationing of such weap-ons on their territories.

Following Russia's pledge to respect Mongolia's NWFZ status, as mentioned earlier, in October 1993 an official American statement, besides offering Mongolia explicit positive and nega-tive security guarantees, stated that if the country ever faced a threat and decided to refer the matter to the United Nation Secu-rity Council, the United States, along with other Council mem-bers, would consider appropriate steps to be taken. By making such statement, the United States has given Mongolia an assur-ance that it would not be indifferent not only to potential nuclear threats to Mongolia but to any conventional threat as well. To-gether with the assurances of respect for sovereignty and territo-rial integrity by its neighbors, this statement represents the basis of international political guarantees of Mongolia's external secu-rity.

A few days after the American statement was issued, the Chinese Foreign Ministry spokesman declared that China supported and welcomed Mongolia's becoming a NWFZ and that it would respect that status. The Chinese pledge was later reiterated in the joint Mongolian-Chinese press statement at the end of Premier Li Peng's visit to Mongolia in April 1994. Soon thereafter Great Britain and France followed suit by explicitly offering Mongolia their negative and positive security assurances. In the summer of 1994 the Non-Aligned Movement, for its part, also commended and expressed support for Mongolia's NWFZ 
status.

Having obtained the support of nuclear-weapons and non-nuclear-weapons states for its NWFZ status, Mongolia, as reflected in its National Security Concept, adopted in the spring 1994 by its Parliament, is working to reinforce its status on the multilateral level and make it an important element in the strengthening of national security by political means. Its long-term goal is to ex-tend this status, if possible, to the Central Asian sub region as a whole, thus expanding the area of nuclear security.

\section{Nuclear Weapons Test Ban}

The NWFZ status, though internationally recognized, does not automatically ensure fully, at least for now, Mongolia's nu-clear security, since nuclearrelated threats do not necessarily come solely in the form of direct or overt threats. They also take the form of indirect threat to the population and the environment as a result of radioactive fallout from nuclear weapons tests both in the atmosphere and underground. Mongolia is more affected than most other countries by nuclear tests and their consequences, due to its proximity of test sites to Mongolian territory. Since the end of World War II, the Soviet Union alone conducted about 715 tests, of which 506 were in the atmosphere. The vast majority of these tests were conducted at the Semipalatinsk test site. China has conducted forty-one testes at the Lop Nor test site, of which twenty-three were in the atmosphere. Both of these test sites are relatively close to the Mongolian border. Today China remains the only nuclear-weapons state that still conducts nuclear weapons tests despite international concern and protests.

The direct and indirect effects of such tests on the population and the environment (e.g. premature deaths, bone cancer, leukemia, genetic mutations, chromosome aberrations, miscarriages and congenital malformations that cause mental and psychological defects) have yet to be fully assessed in Mongolia as they are currently being done in Russia. Mongolia expects its two neighbors as well as relevant international organizations to help fully assess the damage caused by nuclear tests.

On the international level, nuclear weapons tests not only heighten the temptation to "go nuclear". In other words, they contribute to the pressure not only for horizontal proliferation, but also to vertical proliferation of nuclear weapons, aimed at "improving" or "perfecting" the existing arsenals and warheads by developing neutron and other types of bombs, low-weight, high-yield plutonium warheads and the like.

It is for these reasons and to make its contribution to the cessation of all nuclear-weapons tests that Mongolia has always strongly advocated a compre- 
hensive test ban. As a member of the Conference on Disarmament, it is currently taking part in ne-gotiations to draft a comprehensive test ban treaty (CTBT).

In August 1994, the Mongolian delegation introduced a working paper in the Conference's Ad Hoc Committee on a Nu- clear Test Ban. In the paper Mongolia reiterated its belief that in order to strengthen the non-proliferation regime and nuclear se-curity, the Non-Proliferation Treaty should be extended for an indefinite period, and that all states, especially those with nuclear installations, should accede to the existing international treaties and agreements on the physical protection of nuclear material, early notification of nuclear accidents and other relevant interna-tional treaties. Spelling out the reasons that prompted it to de-clare its territory a NWFZ, Mongolia noted that it was surrounded by two nuclear weapons states and that, moreover, the region in which the country is located has a number of near-nuclear states. Addressing the Committee's work, Mongolia stated that an early conclusion and strict implementation of the future multilateral, comprehensive test ban treaty with an effective verification mecha-nism would be the most appropriate way to universally ban nu-clear testing. For the purpose of maintaining a positive atmos-phere and promoting the negotiations, Mongolia called upon all nuclear weapons states to refrain from testing nuclear weapons for the duration of the negotiations.

Bearing in mind its geographical location and geophysical features, which were given in an annex to the working paper, for seismic, radioactive, infrasound and electromagnetic monitoring, and guided by a desire to make practical contributions to a comprehensive text ban, Mongolia proposed to establish an international verification site on its territory, which could form part of the CT; BT global monitoring network. Mongolia's offer was met with interest, and at present informal consultations is underway in Geneva to identify the technical requirements for setting up such a verification site.

\section{Nuclear Waste and Radiation}

Another question that directly affects Mongolia's long-term security interests is the issue of land disposal of nuclear wastes by neighboring states in the vicinity of its territory. This issue is acquiring great urgency especially since the international prohi-bition of dumping of radioactive wastes in oceans by the Conven-tion on the Prevention of Maritime Pollution by Dumping of Wastes and Other Matter. The increased use of nuclear power stations in the world urgently requires that states tackle nuclear waste dis-posal issues with due regard for the interests of neighboring states and the world community as a whole. 
The international community has been dealing with legal aspects of nuclear disposal issues for decades, and not without some results. Besides the above convention, the international community has adopted a Code of Practice on the International Tran boundary Movement of Radioactive Waste, adopted on 21 September 1990 by the General Conference of the IAEA, and some other legal instruments. Moreover, the Conference on Disarmament is currently drafting a convention on the prohibition of radiological weapons, bearing in mind, inter alias, the "long-standing effects of radioactive contamination on living creatures as well as on the environment".

As for the question on the physical disposal of nuclear wastes, scientists in many countries have been working on this problem for more than four decades and still have not been able to come up with any successful solution. So far, no proposal or plan to dispose nuclear waste rules out the possibility of radioactive material leaking into the biosphere.

It is well known that nuclear reactions produce more than 200 by-products, most of which disappear within seconds. Some, however, particularly plutonium 239 (one of the deadliest substances known to mankind), strontium 90, and cesium 137, are not only highly dangerous but also extremely long-lived. Scientists, for example, have calculated that plutonium 239 has a half-life of 24,000 years and that; therefore, in order to be safe, it must be stored for a minimum of ten half-lives, which amounts to a staggering 244,000 years.

Until radioactive wastes are safely disposed of, states will always be exposed to this silent threat, since the radiation produced by the decay of radioactive materials, as defined in the draft convention on radiological weapons, would bring about death, suffering, and environmental disaster and destruction. It is for this reason that the United Nations General Assembly in its reso-lutions on prohibiting the dumping of radioactive wastes has been making specific reference to potential hazards underlying any use of radioactive wastes that would constitute radiological warfare.

It is, therefore, important that states that have nuclear wastes dispose of them in a manner that would not cause damage, di-rectly or indirectly, in the short term or in the long run, to neighboring states. This would be in line with the responsibility that states bear for injurious consequences arising out of acts not prohibited by international law as well as for the damage to the environment, as underlined in the draft code of offenses against the peace and security of mankind.

Since nuclear waste could be considered a gradually ap-plied radiological weapon of mass destruction, it is imperative that states possessing such waste 
give guarantees to their neighbors that they would not dispose of it in a manner that could even indirectly cause damage to the latter.

Due to its geographies location, Mongolia's national interests are directly affected by this problem. Although it is the sovereign right of every state to build nuclear power stations, once a nuclear program is launched, that country should see to it that it does not adversely affect the territorial integrity of neighboring states, let alone threaten their security.

The question of nuclear waste disposal near Mongolia's borders first came up in the mid-1980s when three West German firms announced that China had agreed to rent space in the Gobi Desert for the permanent storage of some 4,000 tons of spent fuel from Western Europe for a reported price of US\$ 5.45 billion. At that time spokesmen for the Chinese Ministry of Nuclear In-dustry and the Chinese Nuclear Energy Corporation confirmed that discussions about longterm storage were underway with the abovementioned firms.

Chinese interest in offering sites in the Gobi Desert for the dumping of nuclear waste became even more evident when they also approached Swiss, French and Japanese representatives. This interest was most probably motivated by a desire to earn hard currency for China's economic development, but acceptance of large amounts of nuclear waste could have also had military implications, since chemical processing of nuclear wastes yields plutonium and enriched uranium which is potentially weapons-grade material. China's decision to negotiate the storing of nuclear wastes in the Gobi Desert was facilitated by the fact that the region is thinly populated, Chinese environmentalists did not have much clout, and Mongolia's objections, if any, could have been ignored. To the relief of Mongols and all other peoples potentially affected by this problem, the deal did not go through for various reasons. There was a general reluctance in the West to deal with China on this politically and strategically sensitive issue, in addi-tion to the German government's opposition because a nuclear processing plant was being contemplated in Germany. Besides, the firms would have required prior approval by the United States which supplied West Germany with most of its nuclear materials. Finally, although China had by that time joined the IAEA, it had not yet agreed to on-site inspections of its storage facilities by Agency inspectors.

In December 1988 the Chinese press reported again that a large waste treatment and disposal base of 20,000 square me-ters was to be constructed by 1995 in Northwest China, in the Gobi Desert along the Silk Road, and that the plant would proc-ess nuclear waste, including spent fuel from China's planned nu-clear power plants, which remains radioactive for thousands of years. With 
regard to high-level radioactive wastes, China report-edly is considering a plan to store and treat them in deeper geo-logical layers, but possible sites have not been disclosed.

China is presently operating two nuclear power plants, at Qinshan in Zhejiang province and Daya Bay in Guangdong province. It is planning to build additional plants because current estimates project an annual energy shortage equivalent to some 150 million tons of standard coal by the year 2000 and 1.2 billion tons by 2050 . The same applies to Russia as well. According to its deputy minister of nuclear energy, the share of electricity generated at nuclear power stations in Russia will grow from 14\% in 1994 to 30-35\% by the year 2010 .

This, understandably, raises the question of safe land disposal of nuclear wastes. In the fall of 1993 the Chinese media announced plans for four or five radioactive waste disposal sites: in the Northwest (Gansu province), Southwest (Sichuan province). South (Guangdong province), somewhere along the border between Anhui, Jiangsi, Jiangsu and Zhejiang provinces, and in the Northeast, possibly in eastern Inner Mongolia. They are all reported to be designed to store and treat low- and intermediate-level radioactive wastes mainly from nuclear power plants. Some-time later, it was announced that surveys and feasibility studies have already been made at the northwestern site and that con-struction work would shortly get underway. The location that the China Daily was referring to is Gansu province which borders on Mongolia's three aimags of Gov'Altai, Bayan-Hongorand Omno-Gov'. It was further reported that the first-phase project of the site would have a storage capacity of 60,000 cubic meters and would go into operation in the mid-1990s. Its second-phase project would expand the site's storage capacity to 200,000 cubic meters.

According to Chinese experts, low-and intermediate-level wastes from nuclear facilities, including power stations, would first be solidified on site and then transported to the disposal site, and that in certain cases liquid waste might also be stored. It is not being ruled out that even waste from the military nuclear industry would not be incorporated into the contemplated national radioactive waste disposal program. This means that the proposed sites might also accept liquid and even high-level wastes.

China's plans for the disposal of nuclear waste raise questions that affect the security interests of Mongolia. The reason is that China plans to go ahead with its plans and store the waste even though there is no guarantee that it, any more than industrialized countries, has a watertight solution to the ultimate disposal of radioactive wastes. The absence of such guarantees entails grave 
risks for the biosphere in general, amid especially for the people living in that region, including the population of Mongolia, and their fragile environment.

Mongolia, like any other country, would not want to have knowingly a potential Chernobyl-type tragedy on its doorsteps anymore than on its territory. Having declared itself a NWFZ, having become a party to the NPT and other relevant conventions and treaties, Mongolia has in effect undertaken a commitment that no nuclear-related threat would come to others from its territory. Therefore, it is natural that, in return, Mongolia can also expect from others to ensure that no nuclear-related threat, whether im-mediate or long-term, will ever endanger Mongolia's national security and its people's well-being and survival.

It is for these reasons that Mongolia expects states, espe-cially its neighbors, to take effective measures to prevent any dumping of nuclear or other radioactive wastes that would in-fringe upon the sovereignty of their neighbors and that the Con-ference on Disarmament, when drawing up a convention on the prohibition of radiological weapons, include radioactive wastes in the scope of the convention. Both of these measures are in line with United Nations General Assembly resolutions on the prohibition of the dumping of radioactive wastes, including its recent resolution 49/75A, adopted on 15 December 1994 without a vote.

In the immediate future Mongolia should approach the Chinese government on this issue so as to be briefed on Chinese plans on this issue, on the geological, hydrological, climatic, seismological and other characteristics of the Gansu site and to seek assurances and acceptable safety guarantees against any possible long-term radiological threat. Qualified technical advice could be sought on this issue from the experts of the IAEA, the United Nations Scientific Committee on the Effects of Atomic Radiation, and from technologically advanced countries. 